\title{
ANALISIS HASIL BELAJAR MAHASISWA PADA POKOK BAHASAN HUKUM OHMDAN KIRCHOFF DALAM MATAKULIAH ELEKTRONIKA DASAR I
}

\author{
Wahyudi \\ Program Studi Pendidikan Fisika FKIP \\ Universitas Mataram \\ Mataram, Indonesia \\ Email : wahyudi.unram@gmail.com
}

\begin{abstract}
The purpose of this description is to analyze the results of student learning physics education in sub subject Ohm's law and Kirchoff laws in subject 1 Basic Electronics and possible solutions, which are expected to minimize the percentage of errors. The author uses quantitative methods to support this description. First of all, I have shared the instruments to students of the third semester. Then from the results obtained, the authors categorize the types of errors, analyze and find the reason of the student errors. Once analyzed, the authors obtain the result that the students' understanding of the application of Ohm's law in category 3, the percentage of the greatest mistakes that $90 \%$, followed by the category 1 by $80 \%$ and the lowest category of $2(20 \%)$. Then from the results of the analysis of Kirchoff laws, obtained the largest percentage error in the category of category 3 by $90 \%$, then $40 \%$ of category 2 and category 1 by $10 \%$. From the analysis it can be concluded that the ability of students to master the fundamental law of electricity is low.
\end{abstract}

Keywords: analysis of learning results, ohm's law, kirchoff laws, categories.

\section{PENDAhuluan}

Berdasarkan UU No 12 Tahun 2012 tentang Perguruan Tinggi menyebutkan pendidikan adalah usaha sadar dan terencana untuk mewujudkan suasana belajar dan proses pembelajaran agar peserta didik secara aktif mengembangkan potensi dirinya untuk memiliki kekuatan spiritual keagamaan, pengendalian diri, kepribadian, kecerdasan, akhlak mulia, serta keterampilan yang diperlukan dirinya, masyarakat, bangsa dan Negara [1].

Untuk mencapai tujuan seperti yang diamanatkan dalam UU tersebut, kualitas proses belajar mengajar menjadi sesuatu yang sangat penting. Hal ini disebabkan karena proses belajar mengajar merupakan kegiatan inti dalam pendidikan. Proses ini terjadi antara dosen dengan mahasiswa yang dipengaruhi oleh hubungan yang berkualitas antara dosen dengan mahsiswa.

Ilmu Fisika adalah ilmu yang mempelajari hukumhukum yang menentukan struktur alam dengan mangacu pada materi dan energi yang dikandungnya [2]. Dengan menggunakan pengertian ini, Ilmuwan menerangkan sifat materi dalam benda, sebagaimana gejala lain yang diamati.

Salah satu cabang ilnu fisika yang wajib diajarkan di tingkat Perguruan Tinggi yang mengambil program studi pendidkan fisika adalah elektronika dasar. Hal ini disebabkan karena elektronika memegang peranan sangat penting dalam era sains dan teknologi seperti saat ini. Disamping itu elektronika juga merupakan jantung penggerak alat-alat industri, seperti pada mesin-mesin pengelola yang berjalan secara otomatis, mesin-mesin penggerak kendali pada sistem peralatan, misalnya pada pesawat terbang dan pabrik. Selain itu peranan elektronika juga sangat diperlukan dalam penelitian ilmu pengetahuan, misalnya kimia fisiak dan biologi yang meliputi peralatan-peralatan yang sangat canggih [3].

Saat ini keberadaan elektronika semakin berkembang dengan adannya mikroprosesor. Dengan menggunakan mikroprosesor, dapat dikembangkan peralatan-peralatan elektronik, mulai dari permainan anak-anak, mesin cuci, hingga peralatan yang berbasis komputer.

Namun demikian, khusus untuk mahasiswa pendidikan fisika, kemampuan mahasiswa dalam membaca dan menganalisis rangkaian elektronika menjadi sangat penting, karena diharapkan bisa digunakan dalam proses pembelajaran di sekolah menengah, termasuk kemampuan untuk memperbaiki peralatan-peralatan laboratorium fisika sekolah yang sederhana. Hal ini disebabkan karena hampir semua peralatan laboratorium sekolah berbasis elektronika. Dengan demikian, keberadaan matakuliah elektronika 
dasar sangatlah penting, agar mereka menjadi guru yang professional, sesuai tuntutan saat ini.

Salah satu pokok bahasan yang dipelajari di matakuliah Elektronika Dasar 1 adalah hukum fundamental tentang kelistrikan. Hukum fundamental kelistrikan yang dimaksud meliputi hukum Ohm dan hukum Kirchhoff. Pembahasan hukum-hukum fundamental tersebut sangat penting, karena berfungsi sebagai alat berfikir untuk menganalisis rangkaian elektronika lebih lanjut. Dengan demikian, jika seseorang menguasai dan memahami tentang hukumhukum fundamental tersebut, maka tinggal selangkah lagi akan dapat menguasai pula tentang rangkaian elektronika. Namun demikian, tingkat penguasaan Mahasiswa tentang hukum fundamental tersebut masih rendah, walaupun sudah pernah dipelajari di nata kuluah Fisika Dasar 2. Hal ini bisa dibuktikan dari hasil ujian tengah semester pada matakuliah Elektronika Dasar 1, di mana hampir $75 \%$ Mahasiswa memperoleh nilai di bawah 65 [4].

Berdasarkan latarbelakang di atas, maka tujuan dari uraian ini adalah untuk menganalisis hasil belajar Mahasiswa pendidikan Fisika pada sub pokok bahasan hukum Ohm dan hukum Kirchoff pada matakuliah Elektronika Dasar 1 dan kemungkinan penyelesaiaanya.

\section{TinjauAn Pustaka}

\section{A. Kesulitan Belajar Mahasiswa}

Kesulitan belajar didefinisikan sebagai kondisi di mana seorang siswa merasa kesulitan dalam menelaah pelajaran karena disebabkan oleh hambatan-hambatan baik dari luar maupun dari dalam siswa tersebut [5]. Hambatan-hambatan yang dialami siswa tersebut dalam mencapai hasil belajar dapat bersifat psikologis, sosiologis dan fisiologis sehingga pada akhirnya dapat menyebabkan prestasi belajar yang dicapainya berada di bawah semestinya. Pendapat lain mengatakan kesulitan belajar adalah suatu kondisi di mana anak didik tidak dapat belajar secara wajar, disebabkan adanya ancaman, hambatan ataupun gangguan dalam belajar [6]. Anakanak yang mengalami kesulitan belajar itu biasa dikenal dengan sebutan prestasi rendah/kurang (under achiever). Anak ini tergolong memiliki IQ tinggi tetapi prestasi belajarnya rendah, yaitu di bawah rata-rata kelas [7]

Dapat disimpulkan bahwa kesulitan belajar ialah suatu keadaan di mana anak didik tidak dapat menyerap pelajaran dengan sebagaimana mestinya, yang disebabkan oleh hambatan-hambatan baik dari luar maupun dari dalam siswa tersebut. Dalam hal ini, kesulitan belajar ini akan membawa pengaruh negatif terhadap hasil belajarnya. Hasil belajar yang baik itu tidak selalu diperoleh oleh anak didik yang memiliki inteligensi di atas rata-rata, namun sebenarnya terkadang bukan inteligensi yang menjadi satu-satunya tolak ukur prestasi belajar. Justru terkadang kesulitan belajar ini juga turut berperan dalam mempengaruhi hasil belajar anak didik.

\section{B. Faktor-faktor yang Mempengaruhi Kesulitan Belajar}

Secara garis besar kelompok siswa berkesulitan belajar dapat dibagi dua. Pertama, yang berkaitan dengan perkembangan (developmental learning disabilities), yang meliputi gangguan motorik dan persepsi, bahasa dan komunikasi, memori, dan perilaku sosial. Kedua yang berhubungan dengan akademik, yakni membaca, menulis, dan berhitung, sesuai dengan kapasitas yang dimiliki, tetapi kedua kelompok ini tidak dapat dipisahkan secara tegas karena ada keterkaitan di antara keduanya[8].

Kesulitan belajar dapat dialami oleh siapa saja, mulai dari siswa yang berkecerdasan rata-rata, sampai yang berinteligensi tinggi. Kesulitan belajar dapat berdampak negatif tidak saja dalam penguasaan prestasi akademik, tetapi juga perkembangan kepribadiannya.

Kesulitan belajar yang dialaminya bukanlah sesuatu yang menetap, sebab intervensi dini dan pendekatan profesional secara terpadu dapat menangani kesulitan belajar yang mereka hadapi.

Sesuai dengan fungsi, peran dan tanggung jawabnya, guru di sekolah reguler memiliki posisi strategis dalam turut membantu siswanya yang berkesulitan belajar. Guru merupakan ujung tombak dalam membantu mengatasi masalah-masalah yang dihadapi para siswanya, termasuk permasalahan yang dihadapi anak kesulitan belajar. Untuk itu, sejalan dengan bervariasinya jenis dan tingkat kesulitan belajar yang dihadapi anak, langkah pertama yang harus dilakukan guru adalah mampu melakukan identifikasi atau penjaringan terhadap mereka melalui pengenalan ciriciri atau karakteristik yang ditampilkannya. Kedua, mampu melakukan assesmen, merumuskan dan melaksanakan program pembelajaran yang sesuai dengan karakteristik, permasalahan, dan kebutuhannya. 
Dan, kemampuan melakukan kerja sama secara terpadu dengan propesi lain yang terkait dengan kondisi anak.

Faktor-faktor yang mempengaruhi belajar secara umum dibagi menjadi dua, yaitu faktor interen dan faktor ekstern [8]. Faktor intern terdiri dari tiga macam, yaitu faktor jasmaniah, psikologis dan kelelahan.

1. Faktor jasmaniah meliputi kesehatan dan cacat tubuh.

2. Faktor psikologis meliputi, intelegensi, perhatian, minat, bakat, motivasi, kematangan dan kelelahan.

Sedangkan faktor eksteren meliputi:

1. Faktor keluarga, yang berupa: cara orangtua mendidik, relasi antar anggota keluarga, Susana rumah tangga, pengertian orang tua, latar belakang kebudayaan dan keadaan ekonomi keluarga.

2. Faktor sekolah, mencakup metode mengajar, kurikulum, relasi guru (dosen) dengan siswa (mahasiswa), relasi siswa dengan siswa, pelajaran dan waktu sekolah. Selain itu juga mencakup standar pelajaran, keadaan gedung, metode belajar dan faktor tugas rumah.

3. Faktor masyarakat, juga merupakan faktor eksteren yang berpengaruh terhadap belajar siswa. Hal ini diakibatkan karena keberadaan siswa di tengahtengan masyarakat. Beberapa faktor masyarakat itu meliputi, kegiatan siswa dalam masyarakat, mass media, teman bergaul, dan bentuk kehidupan masyarakat.

\section{Hukum Ohm}

Salah satu hukum Fisika yang mungkin paling dikenal oleh para Mahasiswa adalah hukum Ohm. Hukum ini ditemukan pada tahun 1827 oleh George Ohm, seorang Fisikawan Jerman yang hidup pada tahun 1787 - 1854[9], yang menghubungkan antara beda potensial listrik, kuat arus listrik dan hambatan listrik. Hukum Ohm berbunyi [10]:

Untuk suatu konduktor logam pada temperature konstan, perbandingan antara perbedaan potensial antara dua titik dari konduktor dengan arus listrik adalah konstan.

Konstanta ini disebut hambatan listrik. Secara matematik, hukum Ohm dapat ditulis:

$$
\begin{gathered}
\text { Hambatan listrik }=\frac{\text { beda potensial listrik }}{\text { arus listrik }} \\
\mathrm{R}=\frac{\mathrm{V}}{\mathrm{I}}
\end{gathered}
$$

Jika hubungan ini digrafikkan, maka akan terlihat seperti gambar (1) di bawah ini. Grafik yang sesuai dengan hukum Ohm ( persamaan 1) disebut grafik Ohmik, sedangkan yang tidak sesuai dengan hukum Ohm disebut non Ohmik.

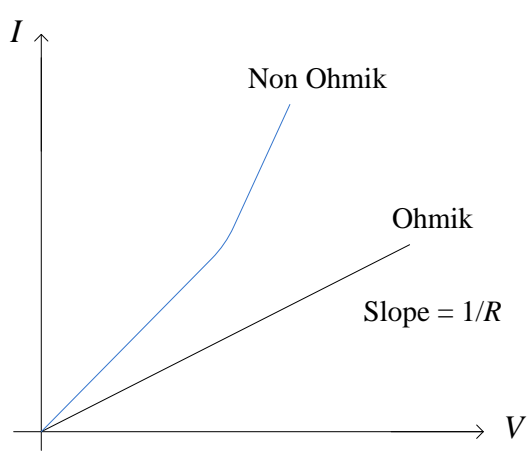

Gambar 1. Kurva I-V untuk Hambatan

\section{Hukum Kirchoff}

Hukum Kirchoff terdiri dari dua persamaan yang membahas tentang kekekalan muatan dan energi dalam rangkaian listrik, dan pertama dijabarkan pada tahun 1845 oleh Gustav Kirchhoff [11]. Hukum Kirchhoff terbagi menjadi dua macam, yaitu Kirchhoff Current Law atau KCL dan Kirchhoff Voltage Law atau KVL[9].

\section{Kirchoff Current Law}

Hukum ini berbunyi:

"Jumlah secara aljabar arus listrik pada suatu titik cabang sama dengan nol”.

Secara ringkas:

$$
\begin{array}{ll}
\sum I_{i}=0 & \sum V=0 \\
\sum \mathrm{I}_{\mathrm{i}}=0 &
\end{array}
$$

Yang dimaksud titik cabang adalah pertemuan antara 3 penghantar atau lebih, yang biasanya ditandai dengan bulatan berwarna hitam. Contoh penerapan KCL adalah seperti dilukiskan pada gambar (2) di bawah ini. 


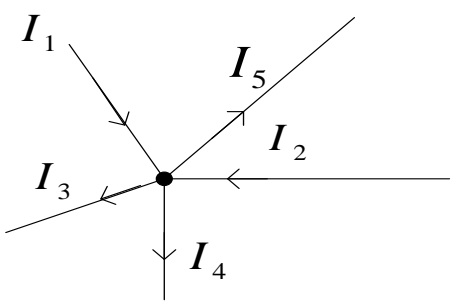

Gambar 2. Lima Penghantar Bertemu Membentuk Titik Cabang.

Penerapan KCL pada gambar (2) didapatkan:

$$
I_{1}+I_{2}-I_{3}-I_{4}-I_{5}=0
$$

Pada persamaan (2) arus listrik yang masuk titik cabang ditandai positif dan yang meninggalkan titik cabang ditandai negatif.

\section{KVL (Kirchoff Voltage Law)}

Hukum Kirchhoff tentang tegangan didasarkan pada hukum kekekalan energi. Ketika muatan listrik q berpindah dari potensial tinggi ke potensial rendah, di mana beda potensialnya $\Delta \mathrm{V}$, maka energi muatan itu akan turun sebesar $\mathrm{q} \Delta \mathrm{V}$. Hukum tegangan Kirchoff berbunyi:

"Jumlah secara aljabar tegangan listrik dalam suatu rangkaian tertutup adalah nol”

Secara ringkas dapat ditulias:

$$
\begin{aligned}
& \sum V=0 \\
& \sum v_{\mathrm{i}}=0
\end{aligned}
$$

Yang dimaksud rangkaian tertutup adalah suatu rangkaian yang terdiri dari sumber tegangan dan beban yang dihubungkan dengan suatu penghantar, sehingga menghasilkan arus listrik. Sedangkan penjumlahan secara aljabar bermakna bahwa tegangan listrik dapat bertanda positif atau negatif bergantung cara memasangnnya.

Sebagai contoh, tinjau rangkaian pada gambar (4) di bawah ini.

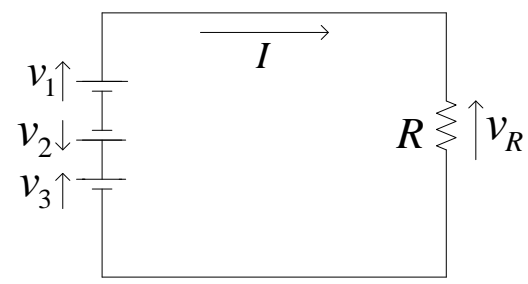

Gambar 3. Rangkaian Listrik Sederhana.
Perhatikan arah anak panah pada masing-masing besaran. Penerapan dari KVL menghasilkan persamaan:

$$
v_{1}-v_{2}+v_{3}-I R=0
$$

Tegangan yang timbul pada hambatan $\mathrm{R}$ ditentukan dengan hukum Ohm, $\mathrm{v}_{\mathrm{R}}=\mathrm{IR}$. Arah sumber tegangan yang searah dengan arah arus yang dihasilkannya ditandai positif (sebagai sumber). Sedangkan arah tegangan yang timbul pada beban (hambatan) selalu berlawanan dengan arah arus (sebagai pemakai). Oleh karena itu tegangan yang timbul pada hambatan $\mathrm{R}$ diberi tanda negatif, yang disebut sebagai tegangan jatuh $(\Delta \mathrm{V}$ $=-\mathrm{IR})$.

Untuk mempermudah memecahkan rangkain yang lebih komplek, yaitu rangkaian yang lebih dari satu loop, agar penerapan hukum Kirchhoff menjadi mudah, dapat digunakan cara sebagai berikut:

1. Penentukan arah arus pada tiap cabang adalah bebas, tetapi akan lebih baik bila konsisten dengan arah arus, yakni dari potensial tinggi menuju potensial rendah.

2. Tentukan arah arus listrik setiap loop, di mana arah loop hendaknya sesuai dengan arah arus litrik yang dipilih. Arah arus dari loop digunakan sebagai dasar untuk menberikan tanda positif atau negatif pada sumber tegangan (V) maupun rugi tegangan (IR) dalam persamaan nantinya.

3. Setelah ditentukan arah arus pada setiap loop, maka dibuat persamaan terhadap tiap loop, di mana arah arus listrik tiap cabang yang searah dengan arah arus yang menuju kutub sumber tegangan, maka kutub sumber tegangan tersebut negative (jatuh tegangan).

4. Apabila nantinya setelah dihitung ternyata harga arus pada cabang tertentu berharga negatif, ini menunjukkan bahwa arah arus yang ditentukan semula adalah salah, sehingga arah arus yang sebenarnya adalah arah sebaliknya.

\section{Hasil dan Pembahasan}

Uraian ini mengkaji permasalahan pokok yang berkaitan dengan kesulitan-kesulitan mahasiswa program studi pendidikan fisika FKIP Unram pada matakuliah elektronika dasar 1 , pada sub pokok bahasan hukum dasar tentang kelistrikan, yang meliputi hokum Ohm dan Kircchoff. Hal ini perlu dilakukan mengingat akan pentingnya hukum dasar tentang kelistrikan sebagai syarat awal dalam mempelajari matakuliah tersebut. Adapaun data yang dipergunakan adalah hasil quiz pada matakuliah Elektronika Dasar I pada 
Mahasiswa Fisika FKIP Unram angkatan tahun 20132014, pada soal hukum Ohm dan Kirchoff.

Data hasil belajar Mahasiswa tentang hukum Ohm yang dianalisis meliputi, (1) penentuan tegangan keluaran pada rangkaian terbuka (2) penentuan tegangan keluaran pada rangkaian tertutup dengan satu hambatan yang dipasang secera paralel dengan sumber tegangan dan (3) penentuan tegangan keluaran pada rangkaian tertutup dengan tiga hambatan yang dipasang secera paralel dengan sumber tegangan.

Sedangkan data hasil belajar Mahasiswa tentang hukum Kirchoff meliputi: (1) menentukan arus listrik pada rangkaian tertutup satu loop dengan dua atau lebih sumber tegangan dan hambatan lsitrik, (2) penentuan arus listrik dengan dua loop akan tetapi menggunakan sebuah sumber tegangan dan (3) penentuan arus listrik pada rangkaian tertutup dengan dua buah loop dan lebih dari satu buah sumber tegangan serta hambatan.

Pengolahan data yang dilakukan dalam analisis hasil belajar ini menggunakan persentase kesalahan pemahaman menggunakan rumus sebagai berikut[12]:

$$
P=\frac{f}{n} \times 100 \%
$$

\section{Keterangan:}

p: persentase kesalahan

$f:$ jumlah jawaban salah dari responden

n: jumlah responden

Hasil dari analisis data adalah seperti dalam uaraian di bawah ini:

1. Hukum Ohm

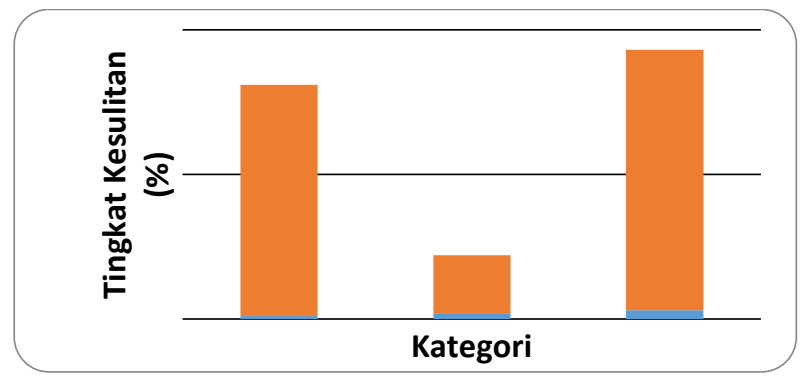

Gambar 4. Grafik Tingkat Kesalahan Versus Kategori pada Hukum Ohm

Berdasarkan grafik batang seperti gambar (5) di atas, dari tiga kategori kesalahan yang dibuat oleh Mahasiswa
Fisika FKIP Unram adalah tingkat kesalahan yang tertinggi adalah penentuan tegangan keluaran pada rangkaian tertutup dengan tiga hambatan yang dipasang secera paralel dengan sumber tegangan yaitu $90 \%$ (ketegori 3). Yang kedua sebanyak 80\% adalah penentuan tegangan keluaran pada rangkaian terbuka (ketegori 1). Sedangkan yang paling sedikit tingkat kesalahanya adalah penentuan tegangan keluaran pada rangkaian tertutup dengan satu hambatan yang dipasang secera paralel dengan sumber tegangan (kategori 2). Kesalahan-kesalahan tersebut diakibatkan karena Mahasiswa kurang memahami bahwa besar tegangan listrik adalah sama bila dipasang secara paralel, tidak bergantung pada besar kecilnya nilai hambatan dan jumlah hambatan. Selain itu pada rangkaian terbuka, tegangan keluaran akan sama dengan tegangan sunber, bila sumber dipasang secara seri dengan hambatan. Mahasiswa beragumentasi bahwa pada rangkaian terbuka tidak ada arus listrik sehingga tegangan listriknya juga tidak ada. Padahal cara menentukan tegangan keluarannya adalah identik dengan mengukur tegangan pada sumber tegangan. Untuk mengatasi permasalahan ini keberadaan eksperimen tentang pengukuran tegangan pada rangkaian terbuka perlu dilakukan dengan lebih optimal.

\section{Hukum Kirchoff}

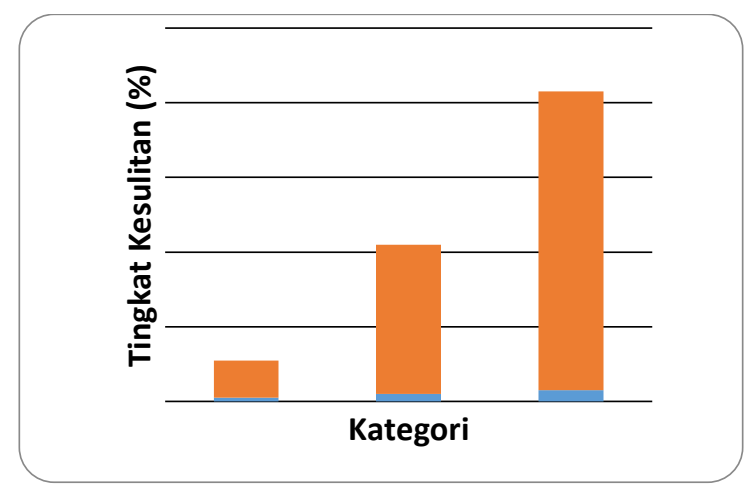

Gambar 5. Grafik Tingkat Kesulitan Versus Kategori pada Hukum Kirchoff

Berdasarkan grafik yang dilukiskan seperti pada gambar (6) di atas, dari tiga kategori kesalahan yang dibuat oleh Mahasiswa Fisika FKIP Unram, tingkat kesalahan yang tertinggi (90\%) adalah penentuan arus listrik pada rangkaian tertutup dengan dua buah loop dan lebih dari satu buah sumber tegangan serta hambatan (kategori 3). Yang kedua sebanyak $40 \%$ adalah penentuan arus listrik dengan dua loop akan tetapi menggunakan sebuah sumber tegangan. Sedangkan tingkat kesalahan terkecil adalah kategori 1, yaitu 
menentukan arus listrik pada rangkaian tertutup satu loop dengan dua atau lebih sumber tegangan dan hambatan listrik. Kesalahan-kesalahan itu disebabkan karena Mahasiswa masih belum memahami istilah penjumlahan secara aljabar, sehingga penentuan persamaan hukum Kirchoff menjadi salah. Istilah tegangan jatuh, yang dalam persamaam matematik diberi tanda negatif, yang berarti sebagai pengguna/konsumsi tegangan (bukan sumber tegangan) masih belum mereka kuasai. Akibatnya sebagin besar Mahasiswa masih belum bisa merapkan hukum Kirchoff dalam bentuk persamaan matematik pada rangkaian, karena mereka kurang memahami kapan tegangan bernilai positif atau negatif.

Dari beberapa temuan di atas, maka perlu dilakukan langkah-langkah umtuk mengatasi kesalahan-kesalahan yang dilakukan Mahsiswa, antara lain Dosen hendaknya mempergunakan metode pembelajaran yang tepat dan bervariasi, memperbanyak latihan soal serta melakukan eksperimen yang optimal. Optimalisasi eksprimen diharapkan terlaksana, karena selama ini pelaksanaan eksperimen elektronika dasar dirasa masih kurang, akibat peralatan yang kurang memadai dan jumlah peserta praktikan yang melebihi batas. Optimalisasi pelaksanaan praktikum ini sesuai dengan tuntutan kurikulum baru.

\section{Penutup}

Berdasarkan uraian di atas dapat disimpulkan bahwa dari tiga kategori kesalahan yang dibuat oleh Mahasiswa Fisika FKIP Unram, pada sub pokok bahasan hukum Ohm, tingkat kesalahan yang tertinggi (90\%) adalah penentuan tegangan keluaran pada rangkaian tertutup dengan tiga hambatan yang dipasang secara paralel dengan sumber tegangan (ketegori 3). Yang kedua sebanyak $80 \%$ adalah penentuan tegangan keluaran pada rangkaian terbuka (ketegori 1). Sedangkan yang paling sedikit tingkat kesulitannya adalah penentuan tegangan keluaran pada rangkaian tertutup dengan satu hambatan yang dipasang secera paralel dengan sumber tegangan (kategori 2).

Sedangakan untuk hukum Kirchoff, tingkat kesalahan yang tertinggi (90\%) adalah penentuan arus listrik pada rangkaian tertutup dengan dua buah loop dan lebih dari satu buah sumber tegangan serta hambatan (kategori 3). Yang kedua terbanyak adalah penentuan arus listrik dengan dua loop akan tetapi menggunakan sebuah sumber tegangan (40\%). Sedangkan tingkat kesalahan terkecil adalah kategori 1, yaitu menentukan arus listrik pada rangkaian tertutup satu loop dengan dua atau lebih sumber tegangan dan hambatan lsitrik (10\%). Untuk meminimalisir kesalahan-kesalahan tersebut, Dosen perlu menggunakan metode pembelajaran yang tepat dan bervariasi, mengoptimalkan pelaksanaan praktikum dan memperbanyak latihan soal.

\section{REFERENSI}

[1] UU no 12 tentang Perguruan Tinggi

[2] Isaac, Alan, (1997), Kamus Lengkap Fisika: Jakarta: Erlangga

[3] Sutrisno, 1986, Elektronika Teori Dasar dan Penerapannya: Bandung ITB

[4] Bagian Akademik FKIP (2014)Universitas Mataram

[5] Abdurahman, Mulyono, (20120 Anak Berkesulitan Belajar, Teori, Diagnosis dan Remediasinya: Jakarta: Rineka Cipta

[6] Syaiful Bahri Djamarah, (2011), Psikologi Belajar: Jakarta: Rineka Cipta

[7] Abu Ahmadi dan Widodo Supriyono, (2013), Psikologi Belajar, (Jakarta: Rineka Cipta).

[8] Slameto, (2010), Belajar dan Faktor-Faktor yang Mempengaruhinya, Jakarta, Penerbit Bineka Cipta.

[9] Warnes , L. A. A, Electronic and Electrical Engineering: Priciples and Practice, London, Macmillan Press, Ltd, 1994

[10] Alonso F., Fin E. J., 2010, Fundamental University Physics, Addison-Wesley Pubhlising Company Inc.

[11] http://id.wikipedia.org/wiki/Hukum_sirkuit_Kirchh off diakses tanggal 11 Maret 2015

[12] Sujana Nana, Ibrahim, 2001, Penelitian dan Penilaian Pendidkan: Bandung, Sinar Baru Algensindo

\section{Biografi Penulis}

Wahyudi, lahir di kecamatan Candipuro, kabupaten Lumajang, Jawa Timur, tanggal 15 Juli 1968. Lulus dari Program Studi Fisika F.MIPA Universitas Brawijaya Malang tahun 1992 dan melanjutkan ke Program Pascasarjana ITB Bandung, jurusan Fisika dan lulus tahun 2002. Mulai Desember 1995 sampai dengan sekarang bertugas sebagai Dosen tetap pada program studi pendidikan Fisika, FKIP Unram, khususnya matakuliah elektronika dasar. Fokus riset pada bidang ilmu fisika teori dan penerapannya. 
